\title{
KEBIJAKAN RESTORATIVE JUSTICE DALAM UPAYA PENANGGULANGAN TINDAK PIDANA MEDIS DI INDONESIA
}

\author{
Bambang Sayekti Setyawan \\ Advokat pada LBH INDONESIA SETARA \\ e-mail: bysetya@gmail.com - bysetya@yahoo.com
}

\begin{abstract}
Abstrak: Tujuan penelitian ini adalah untuk mengetahui bahwa kebijakan restorative justice dapat diterapkan dalam upaya penanggulangan tindak pidana medis dan memiliki prospek yang dapat menjadi solusi komprehensif bagi pelaku tindak pidana medis, korban, masyarakat, dan negara, pada masa yang akan datang di Indonesia. Penelitian ini menggunakan metode kualitatif dengan pendekatan yuridis-normatif. Berdasarkan data dan analisis, penulis mendapatkan jawaban bahwa kebijakan restorative justice dapat diterapkan dalam rangka penanggulangan tindak pidana medis dengan cara nonlitigasi, kuasi litigasi, dan litigasi. Penerapan kebijakan restorative justice yang lebih mengutamakan cara musyawarah untuk mufakat dengan melibatkan pelaku, korban dan/atau keluarga korban, masyarakat, serta penegak hukum, terbukti lebih "kompatibel" dan bermanfaat bagi semua pihak. Oleh karena itu, kebijakan restorative justice memiliki prospek yang baik untuk diterapkan sebagai solusi komprehensif dalam menyelesaikan perkara tindak pidana medis pada masa yang akan datang sebagai ius constituendum. Bagi Indonesia, ternyata restorative justice bukanlah hal yang baru, mengingat nilai-nilainya telah terinternalisasi dalam kehidupan sosial budaya masyarakat dan sejalan dengan falsafah bangsa Indonesia: Pancasila dan UUD 1945. Oleh sebab itu, kebijakan restorative justice dalam upaya penanggulangan tindak pidana medis selain memiliki prospek yang baik juga dirasakan lebih sesuai dan mudah dilaksanakan dengan metode konstruksi, kodifikasi, dan unifikasi. Untuk menjadikannya sebagai hukum positif diperlukan kebijakan hukum untuk melakukan pembaruan hukum pidana di Indonesia sebagai entry point.
\end{abstract}

Kata kunci: restorative justice, tindak pidana medis, dan kebijakan hukum pidana.

Abstract: The purpose of this research is to find out that the restorative justice poli-cy can be applied to prevention in medical crimes and have prospects that can be a comprehensive solution for medical crime offenders, victims, the societies and the state, in the future in Indonesia. This research uses qualitative methods with juridical-normative approaches. Based on data and analysis, the authors get the answer that the restorative justice policy can be applied in the context of the handling of criminal offenses by means of non-litigation, quasi-litigation, and litigation. The application of restorative justice policies that prioritize ways of deliberations to reach consensus by involving perpetrators, victims and/or families of victims, communities, and law enforcers, proved to be more "compatible" and beneficial for all parties. Therefore, the restorative justice policy has good 
prospects to be applied as a comprehensive solution in resolving future medical crime cases as ius constituendum. For Indonesia, evidently that res-torative justice is not new concept, considering that its values have been internalized in the socio-cultural life of the people and in line with the Indonesian philosophy: Pancasila and the Constitution (UUD 1945). Therefore, the restorative justice policy can be applied to prevention in medical crimes beside having good prospects is also felt to be more appropriate and easier to implement with the method of construction, codification, and unification. To make it a positive law, a legal policy is needed to reform criminal law in Indonesia, as an entry point.

Keywords: restorative justice, medical crime, and criminal law policy.

\section{A. PENDAHULUAN}

Hukum di Indonesia mulai kehilangan pamor dan kepercayaan publik. Bahkan, keadaannya pada saat ini "lumpuh" dan telah berada pada titik nadir, kata Sunaryati Hartono. ${ }^{1}$ Hukum tidak mampu menjadi solusi yang komprehensif dalam mengatasi masalah-masalah sosial. Sistem peradilan pidana konvensional yang berlaku selama ini (hukum positif), terutama yang terkait dengan tindak pidana medis, gagal menyelesaikan masalah karena hanya berorientasi pada penghukuman pelaku, sedangkan hak-hak korban diabaikan, masyarakat pun tidak mendapatkan manfaat apa-apa, yang

1 Lihat Orasi Ilmiah Bustanul Arifin di depan Sivitas Akademika Universitas Hasanuddin Makasar, pada 5 Januari 1994, sebagaimana dikutif oleh Achmad Ali dalam bukunya Menguak Tabir Hukum, Penerbit Ghalia Indonesia, Jakarta, 2008, Hlm. 2. terjadi justru menambahi beban negara.

Dihukumnya pelaku - dalam kasus tindak pidana medis berarti dokter - terbukti tidak menyelesaikan masalah, baik bagi pelaku, korban, masyarakat, maupun negara. Bagi pelaku dan korban, penghukuman itu, baik secara fisik, psikis, sosial, maupun ekonomis, tidak mendatangkan manfaat apa pun, kecuali sekadar pembalasan dendam yang bersifat emosional, sehingga secara empiris penghukuman itu sama sekali tidak efektif. Korban dan/atau keluarga korban dalam kasus pidana, misalnya, selama proses penanganan masalah, mulai dari pemeriksaan hingga pelaksanaan hukuman (pemenjaraan), yang bisa memakan waktu tahunan, seakan-akan bukan merupakan bagian dari peristiwa 
hukum yang tengah berlangsung. Korban dan/atau keluarga korban kalaupun sesekali dipanggil, diperiksa, atau didengar kesaksiannya sifatnya hanya sekadar untuk melengkapi keyakinan pemeriksa, yang kadang-kadang justru memerdalam luka psikis korban dan/atau keluarga korban karena harus mengungkapkan lagi kejadian yang memilukannya itu secara berulang-ulang. Apalagi kalau ternyata kasus itu adalah kasus pelecehan seksual atau perkosaan, maka korban dan/atau keluarga korban bukan hal yang mustahil akan semakin menderita dan traumatik. Sesudah palu hakim dijatuhkan dan pelaku dihukum masuk penjara pun, lagi-lagi korban dan/atau keluarga korban juga tidak mendapatkan manfaat apaapa, kecuali sekadar (ada yang merasa) dendamnya terbalaskan. Selebihnya tidak ada manfaat apa pun yang diperoleh oleh korban dan/atau keluarga korban, baik moril maupun materiil.

Bagi masyarakat, kalau yang dihukum tersebut seorang dokter karena dianggap telah melakukan tindak pidana medis, maka jangankan mendapat manfaat, justru dirugikan karena makin berkurangnya kualitas dan kuantitas layanan medis di daerah itu. ${ }^{2}$ Artinya, penghukuman pelaku, terutama seorang dokter yang sangat diperlukan jasa keahliannya demi kemanusiaan, sama sekali tidak memberi manfaat praktis bagi masyarakat.

Kondisi yang menunjukkan adanya disparitas antara harapan dan kenyataan hukum tersebut perlu dilakukan langkah-langkah strategis guna mengembalikan fungsi dan tujuan hukum bagi masyarakat. Un-

2 Lihat dalam M. Ali Firdaus, Dokter Dalam Bayang-Bayang Malpraktik Medik, Penerbit Widya Paramarta, Bandung, 2017, Hlm. 9, terkait dengan kasus bangkrutnya Rumah Sakit Rappahannock (2004) di Negara Bagian Virginia, Amerika Serikat, gara-gara dokter dan rumah sakit tersebut diputus bersalah dan harus membayar miliaran dolar AS untuk penggugat dan membayar pengacara. Akibatnya, sekitar 1,5 juta penduduk Kilmarnock tidak mendapatkan layanan kebidanan yang biasa diberikan oleh rumah sakit tersebut. Lebih jauh, rumah sakit tersebut akhirnya ditinggalkan para pasiennya hingga tak sanggup lagi membayar ribuah pegawainya dan akhirnya bangkrut. Bandingkan pula dengan peristiwa layanan medis di sejumlah pulau di Indonesia Bagian Timur, misalnya di sejumlah kabupaten di Provinsi Papua, yang rasio dokternya sangat rendah, sehingga ada sebagian daerah yang warganya belum pernah mengenal dokter seumur hidupnya. Oleh sebab itu, pemenjaraan seorang dokter sangat merugikan masyarakat. 
tuk itu diperlukan reorientasi kebijakan dan tujuan hukum yang selama ini lebih berorietasi pada upaya mewujudkan keadilan dan kepastian diarahkan pada kemanfaa$\tan$ hukum $;^{3}$ dari penjeraan dan penistaan didorong ke upaya rehabilitasi, reintegrasi, dan pemberdayaan sosial. Itulah yang oleh penulis sebut sebagai kebijakan keadilan restoratif atau yang lebih populer dengan istilan kebijakan restorative justice.

Kebijakan restorative justice merupakan respons sekaligus kritik terhadap pene-rapan sistem peradilan pidana (umum) dengan sistem pemenjaraan yang selama ini beraku terbukti tidak efektif dalam menyelesaikan masalah hukum. Dalam pandangan Marian Leibmann, ${ }^{4}$ konsep penyelesaian masalah pidana dengan pendekatan restorative justice lebih: (1) memrioritaskan

3 Lihat Achmad Ali, Op. Cit., Hlm. 67, bahwa tujuan hukum menurut Gustav Radbruch adalah untuk mewujudkan keadilan, kepastian, dan kemanfaatan hukum. Lihat pula Utility Theory dari Jeremy Bentham dan Hadits Nabi Muhammad saw. yang menekankan bahwa sebaik-baiknya manusia adalah yang bermanfaat bagi sebanyak-banyaknya orang lain.

4 Marian Leibmann, Restorative Justice: How It Works, Jessica Kingsley Publisher, 2007. dukungan dan penyembuhan bagi korban, baik secara fisik maupun psikis; (2) mendorong pelaku untuk memertanggungjawabkan atas perbuatannya kepada korban; mengedepankan dialog atau musyawarah antara korban dan pelaku untuk mencapai kesepakatan yang saling menguntungkan bagi para pihak, sehingga proses penyelesaian sengketa itu mendatangkan manfaat terutama bagi korban dan pelakunya; (4) meletakkan secara benar dan proporsional atas kerugian yang diderita oleh korban yang timbul dari peristiwa hukum tersebut; (5) menyadarkan pelaku dan mencegah timbul atau terulangnya kejahatan baru yang sejenis; dan (6) melibatkan masyarakat dalam proses integrasi antara korban dan pelaku pascakejadian yang ada umumnya terjadi ketidakharmonisan, bahkan saling mendendam, termasuk terjadinya disharmoni tata nilai dalam masyarakat.

Menurut Howard Zehr, restorative justice merupakan kompas, 
bukan peta. ${ }^{5}$ Artinya, restorative justice merupakan petunjuk arah atau guidance yang bersifat dinamis (tidak statis) untuk mendapatkan solusi secara utuh atas masalah hukum yang tengah dihadapi oleh para pihak disesuaikan dengan kondisi masingmasing yang tengah berperkara dengan tidak mengurangi hak masing-masing untuk saling "adu-tawar" guna mendapatkan titik temu yang saling menguntungkan (win-win solution). Adapun menurut salah seorang tokoh penganjur konsep restorative justice, John Braithwaite, restorative justice merupakan arah baru antara justice and welfare models atau antara retribution and rehabilitation. $^{6}$ Maksudnya, restorative justice merupakan model penyelesaian masalah hukum yang berorientasi pada upaya untuk mewujudkan nilai-nilai keadilan sekaligus kesejahteraan atau kemanfaatan atau antara unsur sanksi

5 Howard Zehr, The Little Book of Restorative Justice, Good Books, Intercourse, PA 17534, Hlm. 8 - 12.

6 John Braithwaite, Restorative Justiceand Responsive Regulation, Oxford University Press, New York, 2002, dalam Rena Yulia, Viktimologi Perlindungan Hukum terhadap Korban Kejahatan, 2010, Graha Ilmu, Yogyakarta, Hlm. 161. dan unsur yang bersifat memerbaiki kondisi (terutama ekonomi). Artinya, aspek keadilan dapat dicapai dengan mengedepankan kemanfaatan. Jadi, fokus perhatiannya adalah pada nilai kemanfaatan hokum bagi masyarakat yang sejalan dengan konsep Islam dan teori kemanfaatan Bentham. ${ }^{7}$

Dengan kata lain, kebijakan restorative justice merupakan pembaruan proses peradilan pidana konvensional (yang tidak efektif) menuju penyelesaian yang sesuai dengan keinginan para pihak, yang sejalan dengan semangat, jiwa, dan ideologi bangsa Indonesia untuk menjadikan hukum sebagai solusi komprehensif melalui musyawarah dengan semangat kekeluargaan. Itulah yang oleh Padmo Wahjono sebut sebagai negara hukum berdasarkan Pancasila dan UUD 945. ${ }^{8}$ Hal senada juga dikemukakan oleh Oemar Seno Aji dan Romli Atmasasmita bahwa konsep negara hukum dengan karakteristik pendekatan musyawarah secara

7 Jeremy Bentham, An Introduction to the Principles of Morals and Legislation, Batoche Books, Kitchener, 2000).

8 Padmo Wahjono, Pembangunan Hukum Indonesia, Penerbit Ind-hill Co., Jakarta, 1989, Hlm. 153. 
kekeluargaan adalah Negara Hukum Pancasila. $^{9}$

Tujuan penelitian ini secara umum adalah untuk mengembalikan hukum sebagai sarana penyelesai masalah secara komprehensif yang lebih bermanfaat, bermartabat, dan berkeadilan sosial bagi semua pihak, baik pelaku, korban, masyarakat, maupun negara, sebagaimana amanat Pembukaan UUD $1945 .{ }^{10}$ Secara teoritis, penelitian ini berguna untuk mengembangkan ilmu hukum, khususnya ilmu hukum pidana dan hukum kedokteran/medis. Adapun secara praktis, penelitian ini berguna untuk memberi masukan bagi pemerintah dalam kaitannya dengan penetapan kebijakan hukum pidana; bagi legislatif dalam kaitan dengan pembentukan undang-undang; dan bagi lembaga peradilan, khususnya

9 Romli Atmasasmita, Teori Hukum Integratif (Rekontruksi Terhadap Teori Hukum Pembangunan dan Teori Hukum Progresif), Genta Publishing, Yogyakarta, 2012, Hlm. $101-102$.

10 Dalam Pembukaan UUD 1945 ditegaskan bahwa tujuan negara (hukum) di antaranya adalah untuk meningkatkan kesejahteraan umum, mencerdaskan kehidupan bangsa, yaitu sejalan dengan Teori Hukum Progresif yang dikemukakan oleh Satjipto Rahardjo dan Teori Negara Kesejahteraan dari John Maynard Keynes. peradilan pidana, terutama terkait dengan penerapan dan penegakan hukum.

Pertanyaan problematiknya adalah: (1) bagaimanakah kebijakan restorative justice dapat diterapkan dalam upaya menanggulangi tindak pidana medis; dan (2) bagaimanakah prospek penerapan kebijakan restorative justice dalam upaya menanggulangi tindak pidana medis secara komprehensif di Indonesia?

\section{B. PEMBAHASAN}

Untuk menemukan jawaban secara objektif atas pertanyaan problematik tersebut, metode penelitian yang penulis gunakan untuk mengkaji dan melakukan analisis adalah metode kualitatif dengan pendekatan yuridis normatif. Karakteristik metode kualitatif di antaranya simpulan hasil analisis tidak dapat diukur secara matematik atau statistik, melainkan didasarkan pada kekuatan argumentasi yang dideskripsikan dalam bangunan logika dan penalaran ilmiah.

\section{Perspektif Tindak Pidana Medis}

Dalam perspektif hukum pidana, tindak pidana medis dipandang se- 
bagai kejahatan yang merupakan masalah yang menjadi otoritas negara dan oleh karena itu hanya negara yang berhak menghukumnya, meskipun sebenarnya komunitas adat (artinya bukan hanya negara) juga bisa memberi sanksi pidana yang tidak kalah efektifnya. Namun, karena otoritas negara diberi kewenangan untuk mengambil alih semua peran publik yang terkait dengan pemidanaan, maka hanya negara yang berwenang mewakili publik untuk menyelesaikan masalah hukum pidana. Diakui atau tidak, peran negara dalam kontes penyelesaian masalah hukum pidana acapkali tidak merepresentasikan kepentingan, keinginan, dan tuntutan kebutuhan para pihak, terutama korban dan pelaku. Sebab, dalam faktanya korban hampir selalu tidak mendapatkan porsi perhatian yang cukup memadai, kecuali hanya didengar keterangannya sebagai saksi (saksi korban). Kesaksian korban tersebut pun oleh hakim atas nama netralitas dan integritas hakim - tidak harus dirujuk sebagai pertimbangan utama dalam proses pengambilan putusan pengadilan. Itulah sebabnya sering terjadi antara putusan hakim dan kehendak korban merupakan dua hal yang berbeda yang seolah-olah tidak menunjukkan adanya korelasi. Karena itu pula pemenjaraan pelaku kejahatan sering dianggap sebagai pelampiasan kebencian, balas dendam, dan penistaan masyarakat yang dijalankan oleh negara. Ketidakseimbangan keadaan itulah yang melahirkan gagasan restorative justice sebagai alternatif yang lebih bermanfaat dan sesuai dengan rasa keadilan bagi korban, pelaku, masyarakat, dan negara secara bersama-sama.

Tidak seperti tindak pidana pada umumnya, tindak pidana medis memiliki karakteristik yang spesifik dan dalam beberapa hal kondisinya berbanding terbalik dengan tindak pidana biasa. Misalnya, kalau tindak pidana biasa yang dijadikan fokus perhatiannya adalah akibatnya ( $g e$ volg), namun pada tindak pidana medis yang dijadikan objek perhatian utamanya adalah sebabnya (causa). Sehingga, apapun yang dilakukan oleh seorang dokter, diukur dari sesuai atau tidaknya tindakan medis tersebut dengan ketentuan-ketentuan praktik kedokteran, yaitu: standar 
kompetensi medis, kewenangan medis, standar pelayanan medis, standar prosedur operasional, indikasi medis, informed consent, standar etika kedokteran, disiplin praktik kedokteran, dan peraturan perundang-undangan yang berlaku. Oleh sebab itu, apa pun akibatnya, sepanjang tindakan medis yang dilakukan oleh dokter telah sesuai dengan ketentuan medis tersebut di atas, maka dokter tidak dapat dituntut secara hukum. Hal itu antara lain dibenarkan berdasarkan perjanjian terapeutik yang dibuat antara dokter dan pasien. Dalam perjanjian terapeutik yang dijadikan pedoman dan objek perjanjian atau yang diperjanjikan adalah "upaya yang sungguhsungguh" oleh dokter untuk kesembuhan pasien (inspaning verbintenis), bukan hasil akhir (resultat verbintenis) berupa kesembuhan. ${ }^{11}$

Dengan kata lain, apabila ada tindakan medis yang dilakukan oleh dokter dan telah sesuai dengan ke-

11 Desriza Ratman, Aspek Hukum Informed Consent dan Rekam Medis Dalam Transaksi Terapeutik, Kenimedia, Bandung, 2011, Hlm. 15 - 16. Bandingkan juga dengan Bahder Johan Nasution, Hukum Kesehatan Pertanggungjawaban Dokter, Rineka Cipta, Jakarta, 2005, Hlm 11. tentuaan yang berlaku sebagaimana tersebut di atas, namun berakibat buruk pada pasien, misalnya kondisi pasien semakin memburuk, pasien mengalami cacat fisik secara permanen, atau bahkan meninggal dunia, maka kondisi yang demikian itu termasuk kategori risiko medis, bukan malpraktik medis. Jadi, dalam konteks tindak pidana medis fokus utama pemeriksaan pidana terletak pada penyebabnya (tindakan medis yang dilakukan oleh dokter), bukan akibat yang terjadi pada diri pasien pascatindakan medis.

Dalam kasus tindak pidana biasa, hubungan antara sebab dan akibat dapat ditarik garis langsung. Artinya, antara sebab dan akibat memiliki hubungan kausalitas yang saling terkait atau memengaruhi. Hal itu tidak berlaku dalam kasus tindak pidana medis. Sebab, tindakan medis yang sama (sebagai penyebab) yang dilakukan oleh dokter kepada lebih dari satu pasien, akibat yang timbul atau dialami oleh masing-masing pasien bisa berbeda-beda. Perbedaan akibat yang dialami oleh pasien tersebut sangat dipengaruhi oleh faktor- 
faktor sebagai berikut: ${ }^{12}$ (1) kondisi atau tingkat keparahan penyakit yang diderita oleh pasien pada saat berobat; (2) kondisi daya tahan tubuh pasien; (3) ketersediaan peralatan kesehatan, fasilitas kesehatan, dan obat-obataan pada sarana kesehatan yang bersangkutan; (4) adanya penyakit lain yang timbul tidak dapat diperkirakan sebelumnya (risiko medis); dan (5) adanya penyakit lain yang tidak diketahui oleh pasien dan/atau dokter sebelumnya.

Tindak pidana medis (criminal malpractice) adalah tindakan medis yang memenuhi unsur pidana yang dilakukan oleh tenaga medis: ${ }^{13} 1$. adanya perbuatan/tindakan medis yang bersifat melawan hukum; 2 . dilakukan oleh tenaga medis yang mampu bertanggung jawab; 3. dilakukan dengan sengaja atau alpa; 4 . tidak ada alasan pemaaf. Tindakan medis yang bersifat melawan hukum adalah tindakan yang bertentangan dengan ketentuan-ketentuan praktik

M. Ali Firdaus, Op. Cit., Hlm. 4 - 5.

3 Yang dimaksud dengan "tenaga medis" sebagaimana dimaksud oleh UndangUndang Nomor 36 Tahun 2014 tentang Tenaga Kesehatan, Pasal 11 ayat (2) terdiri atas dokter, dokter gigi, dokter spesialis, dan dokter gigi spesialis. kedokteran. Tenaga medis yang mampu bertanggung jawab adalah tenaga medis yang dalam menjalankan tugasnya dalam keadaan sadar, sehat jasmani-rohani, tidak dalam tekanan dari pihak manapun. Adapun unsur sengaja (intentional), misalnya: melakukan aborsi tanpa indikasi medis, euthanasia, membocorkan rahasia kedokteran, tidak melakukan pertolongan medis dalam kasus gawat darurat, membuat surat keterangaan tidak benar, membuat $v i$ sum et repertum yang tidak benar, dan memberi keterangan yang tidak benar dalam siding pengadilan sebagai ahli. Sedangkan unsur alpa (culpa) adalah bentuk tindakan kurang hati-hati yang menyebabkan, misalnya: tertinggalnya peralatan medis di dalam tubuh pasien pada waktu melakukan tindakan operasi, pasien mengalami luka-luka, dan pasien cacat atau meninggal dunia. Unsur culpa terdiri atas: culpa lata, yaitu tidak hati-hati, sembrono, atau kesalahan serius (gross fault); culpa levis, yaitu kelalaian atau kesalahan biasa (ordinary fault); dan culpa levissima, yaitu kelalaian atau kesalahan ringan (slight fault). Ada- 
pun unsur yang dapat meniadakan pidana (pemaaf) menurut J. Guwandi adalah faktor-faktor khusus yang tidak ditemui dalam hukum yang berla$\mathrm{ku}$ umum, misalnya kecelakaan medis (medical accident) atau risiko pengobatan (risk of treatment). ${ }^{14}$

\section{Objek Penelitian}

Dari tujuh kasus dugaan tindak pidana medis yang terjadi di beberapa daerah, yang penulis teliti, yaitu di Banda Aceh, Medan, Jakarta, Depok, Tasikmalaya, Manado, dan Kerinci, semua diawali dari adanya tindakan/pertolongan medis (sebagai penyebab) kegawatdaruratan pasien dengan indikasi medis yang beragam dan semua berakhir dengan meninggal dunianya pasien - meskipun, sekali lagi, dalam kasus tindak pidana medis antara sebab dan akibat tidak dapat ditarik garis kausalitas. Ketujuh kasus tersebut, keluarga pasien menuntut secara pidana dan perdata, ditambah adanya unsur pemerasan, ancaman, dan intimidasi,

14 J. Guwandi, Hukum Medik (Medical Law), FKUI, Jakarta, 2007. Lihat juga dalam:

http//www.freewebs.com./Kelalaian

Medis dan Unsur-unsur Kelalaian Hukum, Diunduh pada tanggal 2 September 2018, pukul 23.15 WIB. dari pihak lain. Secara pidana, pada umumnya keluarga pasien menjerat dokter dan/atau rumah sakit dengan dugaan terjadi kelalaian medis, kesengajaan, dan perbuatan tidak menyenangkan, dengan Pasal 334, 335, 347, 359, dan 360 KUHP. Sedangkan gugatan perdatanya keluarga pasien menuduh dokter dan/atau rumah sakit telah melakukan perbuatan melawan hukum sebagaimana diatur dalam Pasal 1365, 1366 KUH Perdata dan/atau melakukan wanprestasi sebagaimana diatur dalam Pasal 1239 KUH Perdata, dengan tuntutan ganti rugi materiil dan imatariil yang bervariasi, yaitu antara 10 - 100,65 miliar rupiah.

\section{Cara Penyelesaian Masalah Dugaan Tindak Pidana Medis}

Berdasarkan temuan, hasil kajian, dan analisis yang penulis lakukan, dari ketujuh kasus tersebut dapat diselesaikan dengan cara:

1. Nonlitigasi, yaitu dengan menerapkan konsep pendekatan restorative justice melalui dialog dan musyawarah antarpara pihak yang terkait. Cara ini dipilih dan mampu menyelesaikan secara 
efektif dan efisien sebanyak 5 ka$\operatorname{sus}(71,43 \%)$;

2. Kuasilitigasi, yaitu dengan melibatkan pihak penegak hukum sebagaimana proses litigasi biasa, namun berakhir dengan perdamaian secara dialogis (nonlitigasi). Cara ini mampu menyelesaikan masalah sebanyak 1 kasus $(14,29 \%)$; dan

3. Litigasi, yaitu menggunakan pendekatan hukum pidana murni. Cara ini mampu menyelesaikan sebanyak 1 kasus (14,28\%).

Dengan kata lain, pendekatan restorative justice dipilih oleh sebagian besar para pihak, yaitu 6 dari 7 kasus $(85,72 \%$ atau $86 \%)$ sebagai jalan keluar untuk menyelesaikan dan mengakhiri perselisihan medis antara dokter dan rumah sakit (pada satu pihak) dan pasien dan/atau keluarga pasien (pada pihak lain). Hal tersebut menunjukkan bahwa kebijakan restorative justice dalam penyelesaian perkara dugaan adanya tindak pidana medis, merupakan solusi yang dianggap paling bermanfaat, bermartabat, berkeadilan, dan lebih menguntungkan para pihak, baik bagi korban, pelaku, masyarakat, maupun negara, apabila dibandingkan dengan penyelesaian melalui jalur pengadilan (litigasi).

a. Bagi pasien dan/atau keluarga pasien selaku korban, penerapan sistem peradilan pidana umum untuk menyelesaikan perkara pidana medis selalu menyisakan masalah baru bagi bagi dirinya karena tidak pernah diikutsertakan dalam proses penyelesaian masalah dalam persidangan di pengadilan kecuali hanya didengar sebagai saksi; pemidanaan atau pemenjaraan bagi pelaku tindak pidana sama sekali tidak memberi manfaat apa pun bagi korban dan/atau keluarga korban, karena faktanya banyak korban dan/atau keluarga korban pascapelaksanaan vonis hakim hidupnya semakin sulit atau berat, baik secara psikologis maupun secara ekonomis. Hal tersebut tidak akan terjadi apabila penyelesaian perkara pidana medis dilakukan berdasarkan pendekatan restorative justice karena korban akan diberdayakan, diberi kompensasi secara moril dan materiil oleh pelaku tindak pidana, serta mas- 
ing-masing pihak telah saling memaafkan.

b. Bagi dokter sebagai pelaku, penerapan sistem peradilan umum untuk menyelesaikan perkara pidana medis selalu menimbulkan masalah baru karena dokter harus menjalani proses hukum yang lama dan berbelit-belit yang menyita banyak waktu, tenaga, dan pikiran selama menjalani proses hokum, sehingga memecah konsentrasi dokter dalam menjalankan tugasnya. Hal itu mengakibatkan timbul rasa frustrasi karena tekanan psikologis selama menjalani proses hokum, apalagi jika proses hukum tersebut berakhir dengan vonis hukuman penjara, maka seorang dokter yang biasanya menjalankan profesi mulia dan terhormat (Officium Nobile) mendapat perlakuan tidak ubahnya dengan seorang pencuri atau pembunuh, sehingga timbul trauma psikologis yang serius. Hal tersebut tidak akan terjadi apabila penyelesaian perkara pidana medis menggunakan pendekatan restorative justice karena $\mathrm{pu}-$ tusannya berdasarkan hasil per- musyawaratan dan permufakatan bersama.

c. Bagi masyarakat, penerapan hukum pidana konvensional untuk menyelesaikan perkara pidana medis tidak memberikan pemulihan kerusakan tatanan sosial di dalam masyarakat. Jatuhnya vonis hakim berupa pemidanaan atau pemenjaraan terbukti tidak memberikan efek jera, sehingga kasus demi kasus sejenis terus terjadi dari waktu ke waktu. Dalam hal penyelesaian perkara pidana medis tersebut dilakukan dengan pendekatan restorative justice maka kerusakan tatanan sosial tersebut dapat dengan mudah dipulihkan karena pelaku diberi tanggung jawab untuk melakukan social recovery.

d. Bagi negara, penerapan hukuman penjara berdasarkan vonis hakim dalam kasus tindak pidana, termasuk pidana medis, menambah beban keuangan yang sangat berat, yaitu terkait dengan terbatasnya ketersediaan gedung atau kapasitas ruang penjara (lapas), terbatasnya anggaran untuk menata kelola penjara (lapas), 
dan terbatasnya sumber daya manusia, baik secara kualitas maupun kuantitas. Hal demikian itu dapat diatasi dengan penggunaan pendekatan restorative justice dalam penyelesaian perkara pidana, karena negara tidak perlu menyediakan semua itu. Bahkan, di sejumlah negara yang telah melaksanakan pendekatan restorative justice penjaranya kosong dan dapat digunakan untuk kepentingan lain.

\section{Formula Solusi Restorative Jus- tice}

Berdasarkan analisis penyelesaian masalah, baik yang dilakukan dengan cara nonlitigasi maupun kuasilitigasi, melahirkan formula solusi yang sama, yang secara umum diterima oleh semua pihak, terutama pihak korban dan pelaku, yaitu berbentuk: (1) pemberdayaan korban/keluarga korban dengan pemberian bantuan ekonomi jangka panjang oleh pelaku, misalnya berupa bantuan modal usaha dan/atau pemberian pekerjaan; (2) pelaku memberi kompensasi dalam bentuk uang dengan jumlah tertentu yang disepakati bersama se- bagai ganti rugi kepada korban/keluarga korban; (3) pernyataan dan permohonan maaf dari pihak pelaku kepada korban dan/atau keluarga korban serta masyarakat secara terbuka melalui media massa; (4) permohonan maaf dari pelaku secara pribadi atau kekeluargaan kepada korban/keluarga korban dan masyarakat; dan (5) pengakuan menjadi keluarga atau famili oleh pelaku kepada korban/keluarga korban, misalnya sebagai anak asuh, orang tua asuh, keluarga angkat, dan sebagainya.

\section{PENUTUP}

\section{Simpulan}

Berdasarkan telaah kritis dan analisis atas kasus dan data yang menjadi objek penelitian ini, penulis mendapatkan simpulan yang memberikan jawaban atas pertanyaan problematik tersebut sebagai berikut.

a. Bahwa kebijakan restorative justice dapat diterapkan untuk menanggulangi tindak pidana medis secara efektif dengan cara: (1) nonlitigasi, (2) kuasilitigasi, dan (3) litigasi. Kebijakan restorative justice terbukti lebih efektif untuk 
penanggulangan tindak pidana medis daripada hukum pidana positif yang selalu menyisakan masalah bagi korban, pelaku, masyarakat, dan negara.

b. Bahwa kebijakan restorative justice memiliki prospek yang baik dalam upaya penanggulangan tindak pidana medis karena secara empiris sejalan dengan nilai-nilai sosial budaya yang ada, tumbuh, dan berkembang di dalam masyarakat, juga sejalan dengan falsafah bangsa Indonesia, Pancasila. Jadi, kebijakan resto-rative justice merupakan hukum masa depan (ius constituendum) yang penerap-annya dapat dilakukan dengan metode: konstruksi, kodifikasi, dan unifikasi.

\section{Saran}

Untuk mewujudkan harapan di atas, penulis menyarankan kepada:

a. Pemerintah agar menetapkan politik hukum nasional yang sejalan dengan cita-cita nasional, falsafah negara Pancasila, dan UUD 1945 untuk menentukan sistem hukum Indonesia dan roadmap politik hukum pidana di Indonesia yang sejalan dengan semangat restora- tive justice guna menggantikan sistem hukum peninggalan kolonial Belanda yang sudah usang. Untuk itu, para akademisi dan pembentuk undang-undang perlu melakukan kajian akademik dan transformasi konsep Hukum Barat, yaitu sistem Anglo Saxon dan Eropa Kontinental, hukum Islam, dan hukum adat ke dalam sistem hukum nasional, sehingga melahirkan satu sistem hukum nasional yang berfilsafatkan Pancasila dan UUD 1945.

b. Dalam jangka pendek, Majelis Kehormatan Etika Kedokteran (MKEK) dan Majelis Kehormatan Disiplin Kedokteran Indonesia (MKDKI) perlu diperkuat dan diperluas tugas pokok, fungsi, dan kewenangannya dalam menyelesaikan sengketa medis melalui proses mediasi, ajudikasi, arbitrasi, dan bentuk-bentuk fasilitasi lain yang mengedepankan dialog secara musyawarah dan kekeluargaan guna menyelesaikan masalah secara komprehensif. Dalam dalam jangka panjang, negara melalui kekuasaan kehakiman perlu membentuk lembaga peradi- 
lan khusus yang menangani sengketa medis, yaitu lembaga peradilan medis guna menjamin standar profesi hukum dan profesi kedokteran yang lebih profesional dan independen.*

\section{DAFTAR PUSTAKA}

Achmad Ali, Menguak Tabir Hukum, Ghalia Indonesia, Jakarta, 2008.

Ahmad Rifai, Penemuan Hukum Oleh Hakim dalam Perspektif Hukum Progresif, Cetakan Kedua, Sinar Grafika, Jakarta, 2011.

Ali Firdaus, Dokter Dalam Bayangbayang Praktik Medik, WidyaParamarta, Bandung, 2017.

Andi Hamzah, Sistem Pidana dan Pemidanaan, Pradnya Paramita, Jakarta, 1993.

Anny Isfandyarie, Malpraktek dan Risiko Medik dalam Kajian Hukum Pidana, Prestasi Pustaka Publiser, 2005.

Bagir Manan, Retorative Justice (Suatu Perkenalan), dalam Refleksi Dinamika Hukum Rangkaian Pemikiran dalam dekade Terakhir, Perum Percetakan Negara RI, Jakarta, 2008.

Bahder Johan Nasution, Hukum Kesehatan Pertanggungjawaban Dokter, Cetakan Pertama, Rineka Jaya, Jakarta, 2005.
Barda Nawawi Arief, Bunga Rampai Kebijakan Hukum Pidana, Citra Aditya Bakti, Bandung, 1996.

Braithwaite, John, Restorative Justice and Responsive Regulation, Oxford University Press, New York, 2002.

Desriza Ratman, Aspek Hukum Informed Consent dan Rekam Medis Dalam Transaksi Terapeutik, Kenimedia, Bandung, 2011.

Dey Ravena dan Kristian, Kebijakan Kriminal (Criminal Policy), Penerbit Kencana, Jakarta, 2017. Rena Yulia, Viktimologi, Perlindungan Hukum Terhadap Korban Kejahatan, Graha Ilmu, Yogyakarta, 2010.

Eva Achjani Zulfa, Keadilan Restoratif, Badan Penerbit FH UI, Jakarta, 2009.

Gustaf Radbruch, Outline of Legal Philosophy, (terjemahan), YBP Gajah Mada, Yogyakarta, 1957.

Jeremy Bentham, An Introduction to the Principles of Morals and Legislation, Batoche Books, Kitchener, 2000).

J. Guwandi, Hukum Medik (Medical Law), FKUI, Jakarta, 2007.

Marian Leibmann, Restorative Justice: How It Works, Jessica Kingsley Publisher, 2007.

Oemar Seno Aji, Peradilan Bebas Negara Hukum, Erlangga, Jakarta, 1980. 
Bambang Sayekti Setyawan, Kebijakan Restorative Justice Dalam Upaya Penanggulangan Tindak..

Padmo Wahjono, Pembangunan Hukum Indonesia, Penerbit Indhill Co., Jakarta, 1989.

Romli Atmasasmita, Teori Hukum Integratif (Rekontruksi Terhadap Teori Hukum Pembangunan dan Teori Hukum Progresif), Genta Publishing, Yogyakarta, 2012.

Satjipto Rahardja, Membedah Hukum Progresif, Kompas, Jakarta, 2007

Sunaryati Hartono, Politik Hukum Menuju Satu Sistem Hukum Nasional, Alumni, Bandung, 1991.

Zehr, Howard, The Little Book of Restorative Justice, Good-Books, Intercourse, 2002.

Eva Achjani Zulfa, 2015, Makalah: Mendefinisikan Keadilan Restoratif, http://evacentre.blog spot.com/2015/11/definisikeadilan-restoratif.html, diunduh pada hari diakses pada Selasa 28 November 2017, pukul 11.33 WIB.

http://insanakademis.blogspot.co.id/2

011/10/teori-welfare-statemenurut-John-Maynard

Keynes.html. Diunduh pada hari Jumat, 26 Januari, pukul 11.33 WIB.

Undang-Undang Dasar Negara Republik Indonesia Tahun 1945 setelah Amandemen ke-4.

Undang-Undang Republik Indonesia Nomor 1 Tahun 1946 tentang Peraturan Hukum Pidana (KUHP).
Staatsblaad Nomor 23 Tahun 1847 tentang Burgerlijk Wetboek Voor Indonesie (KUH Perdata).

Undang-Undang Republik Indonesia Nomor 29 Tahun 2004 tentang Praktik Kedokteran.

Undang-Undang Republik Indonesia Nomor 36 Tahun 2009 tentang Kesehatan.

Undang-Undang Republik Indonesia Nomor 44 Tahun 2009 tentang Rumah Sakit.

Undang-Undang Republik Indonesia Nomor 48 Tahun 2009 tentang Kekuasaan Kehakiman.

Undang-Undang Republik Indonesia Nomor 36 Tahun 2014 tentang Tenaga Kesehatan.

Keputusan Menteri Kesehatan Republik Indonesia No. 434/Men.Kes/SK/X/1983 tentang Kode Etik Kedokteran Indonesia (KODEKI) 